\title{
Pengaruh Teams Game Tournament Terhadap Prestasi Belajar Matematika Siswa
}

\author{
Qurrota A'yun'), Dimas Anditha Cahyo Sujiwo ${ }^{2)}$ \\ 1) Universitas Muhammadiyah Jember, ${ }^{2)}$ IKIP PGRI Jember \\ Email: qurrota.ayun@unmuhjember.ac.id
}

\begin{abstract}
Cooperative learning is a learning model that emphasizes cooperation and exchanging ideas between group members in achieving predetermined learning goals. This cooperative learning gives all students the opportunity to work hand in hand to complete the given task. The activities in this learning give a great responsibility to each student in the tasks in the group. In this study the game used is to use puzzle games in learning activities. This puzzle is a teaching aid that has the benefit of helping students understand mathematics subject matter. Furthermore, this study uses a one-group pretest postest design. This type of research is used to measure the beginning of a group or class called a pretest and then given a stimulus and then do a measurement again called the posttest. The collected data is then calculated using the $t$ test. Analysis conducted to determine whether there is an effect of Teams Game Tournament learning on the learning legitimacy of students. Based on the discussion and results of this study, the data for $\mathrm{a}=5 \%$, dk 25 obtained $\mathrm{t}$ count $=3.18$ which indicates that the $t$-value is more than the $t$-table value, this value causes that for $\mathrm{Ha}$ accepted while $\mathrm{H} 0$ is rejected, the conclusion is that the average value of students after taking the Teams Game Tournament action is more than the average value before giving the Teams Game Tournament learning action. Based on this analysis, there is an effect of Teams Game Tournament learning towards students' mathematics learning achievement.
\end{abstract}

Keywords : Teams Game Tournament, Puzzle Game, Learning Achievement

\begin{abstract}
ABSTRAK
Pembelajaran kooperatif adalah suatu model pembelajaran yang menekankan dalam kerjasama dan bertukar pikiran antar anggota kelompok dalam mencapai tujuan pembelajaran yang telah ditetapkan. Pembelajaran koperatif ini memberi peluang untuk seluruh siswa saling bahu membahu menyelesaikan tugastugas dalam kegiatan pembelajaran. Setiap aktivitas pembelajaran ini memberi tanggung jawab besar terhadap setiap siswa dalam tugas-tugas dalam kelompoknya. Dalam penelitian ini Game yang digunakan adalah menggunakan game puzzle dalam kegiatan pembelajarannya. Puzzle ini adalah sebuah alat peraga yang memiliki
\end{abstract}


manfaat dapat membantu siswa dalam memahami materi pelajaran matematika. selanjutnya one-group pretest postest desain merupakan rancangan penelitian ini. Jenis penelitian ini digunakan untuk mengukur awal suatu kelompok atau kelas yang disebut pretest kemudian diberikan sebuah stimulusrangsangan lalu dilakukan pengukuran kembali yang disebut postest. Data-data yang terkumpul selanjutnya dihitung menggunakan uji t. Analisis yang dilakukan untuk mengetahui apakah ada pengaruh pembelajaran Teams Game Tournament terhadap sahil belajar siswa. Berdasarkan pembahasan dan hasil penelitian ini didapatkan data untuk a $=5 \%$, dk 25 diperoleh t-hitung $=3,18$ yang menunjukkan bahwa nilai $t$-hitung lebih dari nilai t-tabel, nilai tersebut menyebabkan bahwa untuk $\mathrm{H}_{\mathrm{a}}$ diterima sementara untuk $\mathrm{H}_{0}$ ditolak, kesimpulannya bahwa rata - rata nilai siswa setelah dilakukan tindakan pemberian Teams Game Tournament lebih dari rata-rata nilai sebelum pemberian tindakan pembelajaran Teams Game Tournament. Berdasarkan analisis yang dilakukan ini, menunjukkan terdapat pengaruh pembelajaran Teams Game Tournament terhadap prestasi belajar matematika siswa.

Kata Kunci : Teams Game Tournament, Game Puzzle, Prestasi Belajar

\section{PENDAHULUAN}

Pemebelajaran merupakan sebuah korelasi komunikasi yang terjadi dalam aktivitas belajar antara siswa dengan guru untuk saling bertukar dan menyampaikan berbagai informasi. Aktivitas yang terjalin dapat berupa suatu tindakan guru untuk memfasilitasi berbagai kegiatan yang dilaksanakan oleh siswa untuk mencapai perbuhan tingkah laku yang diharapkan. Perubahan-perubahan tingkah laku ini dihubungkan dengan capaian tujuan pembelajaran. Berbicara pembelajaran dalam dunia pendidikan, maka pembelajaran yang dilaksanakan di sekolah merupakan suatu bagian dari aktivitas pendidikan yang memiliki nilai penting untuk kita soroti, hal ini dikarenakan sekolah merupakan ujung tombak bagi dunia pendidikan di Indonesia ini. Tidak dapat kita pungkiri bahwasanya masa di sekolah memakan waku lebih banyak dibanding disaat kita belajar di perguruan tinggi. Sekolah juga merupakan tempat kita belajar mengenai berbagai bidang ilmu sebelum kita belajar mengenai bidang ilmu khusus yang menjadi keahlian kita dalam bekerja nanti. Pendidikan dapat membawa perubahan bagi seluruh pelakunya. Tentunya dengan pendidikan yang baik di sekolah akan membawa suasana yang baik dan menguntungkan untuk siswa dalam kehidupannya.

Indikator tercapainya pendidikan di sekolah yang baik, salah satunya dalam hal kegiatan belajar mengajar. Proses kegiatan belajar mengajar menjadi poros 
penting untuk pendidikan di Indonesia. Seluruh komponenn pendidikan harus salaing bersinergi agar mutu pendidikan di Indonesia menjadi baik. Perlu yang namanya kesiapan dan kesesuaian antara perencanaan yang kita buat sebagai guru dengan pelaksanaan kegiatan belajar mengajar. Seperti bagaimana rencana dirancang sesuai proses pembelajaran yang telah dan akan berlangsung, seperti apa guru mengajar dalam awal, bagaimana penyampaian materi pelajarannya, dan bagaimana menutup pelajaran, serta bagaimana aktifitas siswa yang terjadi dalam proses pembelajaran ini apakah aktif atau pasif dan sebagainya.

Aktivitas proses belajar mengajar yang baik tentunya akan menghasilkan target tujuan pembelajaran akan tercapai yang diikuti dengan siswa dapat menyerap topik pelajaran. Kegiatan ini tentunya berkaitan dengan strategi mengajar yang dipakai. Guru perlu melakukan kegiatan seperti namanya "planning" sebelum melaksanakan penerapan pembelajaran yang akan disampaikan. Tujuannya agar setiap guru memiliki kesiapan dalam hal kegiatan belajar mengajar demi penyampaian materi pelajaran yang tepat sasaran. Dengan strategi pembelajaran yang telah direncanakan dan dibuat, maka ada kemungkinan besar materi pelajaran yang disampaikan akan diterima seluruh siswa.

Namun secara fakta, dilapangan masih banyak terjadi kendala-kendala dalam dunia pendidikan yang berkaian dengan proses belajar mengajar. Dalam hal proses pembelajaran, Megawanti (2015) menjelaskan bahwa kinerja guru di kelas pun kadang hanya sebatas setor muka dengan para siswa, memberi catatan untuk disalin di buku, memberi tugas untuk dinilai kapan-kapan, atau mengatrol nilai siswa agar pengisian raport cepat selesai dan memenuhi SKBM atau KKM. Hal ini perlu dilakukan suatu perubahan dan pembaharuan agar setiap aktivitas dapat dinikmati siswa- siswa dengan nyaman.

Kendala-kendala pembelajaran dapat kita lihat atau amati dari dua aspek, yaitu kegiatan pembelajaran yang guru laksanakan dan setiap aktivitas siswa di kelas dalam mengikuti kegiatan belajar mengajar. Dalam hal pembelajaran yang guru terapkan di kelas, pembelajaran ini cenderung berpusat pada guru. Artinya dalam kegiatan belajar mengajar guru menjadi peran yang melakukan eksekusi seluruh kegiatan belajar mengajar, sehingga siswa menjadi penerima penyampaian materi 
pelajaran semata. Guru selalu menjadi bagian pembelajarannya yang hanya menjelaskan materi pelajaran sekaligus memberi contoh soal dan penyelesaiannya sehingga siswa hanya menerima informasi materi pelajaran tanpa melakukan kegiatan belajar mengajar. Pembelajaran seperti ini dapat menjadi kendala untuk mencapai keberhasilan pembelajaran (Staples, 2008). Kegiatan seperti ini memberi dampak kurang baik bagi siswa karena diakhir kegiatan siswa selalu mengerjakan latihan soal secara mandiri. Model pembelajaran yang dilakukan akan berdampak kurang baik kepada siswa. Diswa tidak dilatih secara mandi untuk melakukan kegiatan belajar mengajar. Siswa secara mandiri mengerjakan (latihan) latihan soal yang sebelumnya diberi informasi mata pelajaran oleh guru.

Setiap guru perlu melakukan rancangan dan menentukan model pembelajaran agar memberi pengalaman hidup yang baik untuk selurh siswa. Perlu yang namanya suatu perubahan yang mendasar dalam kegiatan sistem pembeljaran. Sistem pembelajaran yang awal mula berpusat pada guru diubah berpusat pada siswa. Hal ini agar seluruh siswa berperan aktif selama mengikuti pembelajaran. Tentunya perlu dukungan dan bimbingan guru dalam setiap aktivitas yang dilakukan oleh setiap siswa. Dengan kata lain peran guru berubah yang sebelumnya menjadi peyampai seluruh informasi materi pelajaran menjadi fasilitator dan pembimbing terutama bagi siswa yang mengalami kesulitan belajar dalam menyelesaikan permasalahan dalam setiap aktivitas pembelajaran. Dengan kegiatan pembelajaran ini, diharapkan siswa mempunyai inisiatif untuk bertanya ataupun mengerjakan soal di depan tulis dan juga melakukan kegiatan diskusi dengan baik, Kegiatan pembelajaran ini juga dapat memberi efek positif, salah satunya siswa terfokus dan memperhatikan proses pembelajaran di kelas. Hal-hal yang menjadi kendala pembelajaran dapat di minimalisir sehingga proses belajar menjadi lebih baik.

Pemilihan model pembelajaran pada dasarnya sebagai upaya prestasi belajar siswa dapat meningkat. Prestasi belajar adalah kemampuan yang dicapai setiap siswa setelah mengikuti kegiatan pembelajaran berdasarkan pengukuran tertentu. Salah satu yang harus diperbaiki untuk meningkatkan prestasi belajar matematika yaitu aktivitas belajar mengajarnya atau yang sering kita kenal dengan model pembelajarannya. Oleh karena setiap guru perlu memperhatikan langkah-langkah kegiatan pembelajaran untuk tercapai hasil yang maksimal dari setiap siswa. 
Suwarkono dkk (2008: 68) menjelaskan bahwasanya prestasi belajar matematika adalah hasil belajar yang dicapai siswa setelah belajar matematika. Tentunya prestasi belajar ini dihasilkan dari pemahaman siswa itu sendiri terhadap topik yang telah dipelajari. Penggunaan strategi yang oriantasinya berpusat pada siswa dimana siswa berperan dalam aktivitas pembelajarannya, maka kemungkinan besar hasilnya akan baik. Pernyataan ini didukung oleh Kadir (2005: 223) "Prestasi belajar matematika merupakan salah satu ukuran tingkat keberhasilan siswa setelah menjalani proses belajar."

Ketidaktepatan guru dalam memilih model pembelajaran juga sangat memungkinkan siswa menjadi pasif, bahkan mungkin menjadi kehilangan keaktifannya. Jadi pemilihan model pembelajaran yang tepat memungkinkan siswa untuk memahami materi secara bermakna yang mengakibatkan pemahaman yang diperoleh berguna seumur hidup. Hamalik (2001) menjelaskan para guru harus memiliki keterampilan memilih dan menggunakan metode mengajar untuk diterapkan dalam sistem pembelajaran yang efektif. Ketepatan pemilihan model pembelajaran menyebakan siswa aktif dalam kegiatan pemebelajaran, dampaknya setiap siswa berperan besar dalam aktivitas pembelajarannya.

Team Game Tournament merupakan model pembelajaran dengan rancangan seperti STAD tetapi perbedaannya terletak pada kuis yang diganti dengan turnamen mingguan (Slavin: 2005). Pemilihan pembelajaran TGT ini berdasarkan pada situasi siswa di kelas yang menunjukkan kurangnya peran siswa dalam pembelajaran dikarenakan siswa tidak diikutsertakan dalam proses pembelajaran. dalam tahap TGT ini terdapat bagian permainan yang disebut Game dimana dalam aktivitasnya terdapat dimensi kegembiraan/kesenangan anak (artinya melalui kegiatan game ini siswa berpeluang untuk tidak merasa bosan dan berpeluang besar untuk antusias dalam kegiatan pembelajaran) memperoleh pengalaman belajar sambil bermain dengan senang dan menantang. Selain itu, tahap lain TGT terdapat tahap penghargaan yang dapat memberi memotivasi besar terhadap siswa agar giat belajar dalam kegiatannya.

Tahap pelaksanaan TGT ini menurut Slavin (2005) bahwa pembelajaran kooperatif tipe TGT dibagi menjadi lima tahap yaitu Class-Presentation (penyajian), 
Team (grup), Game, Tournament (kompetisi) dan Team -Recognize. Belajar sambil bermain tentunya memberi efek positif yang lebih terhadap prestasi belajar matematika siswa karena melalui penggunaan model seperti ini mampu melibatkan seluruh siswa menjadi belajar aktif dalam kegiatan belajar mengajar dan bermain bersama kelompoknya. Sadiman (2008) menjelaskan bahwa sebagai media pembelajaran, permainan dapat diartikan sebagai kegiatan menyenangkan untuk setiap siswa, sesuatu yang menarik serta memungkinkan adanya partisipasi aktif dari siswa. Lebih lanjut Ke \& Grabowski (2007) berpandapat bahwa permainan lebih efektif daripada latihan yang dilakukan secara rutin dalam pembelajaran matematika dan permainan secara kooperatif juga lebih efektif daripada permainan secara individual dalam meningkatksn sikap positif pada matematika.

\section{METODE PENELITIAN}

Metode yang digunakan adalah penelitian kuantitatif. Sugiyono (2011:7) menjelaskan bahwa penelitian kuantitatif merupakan metode penelitian yang digunakan untuk meneliti pada populasi atau sample tertentu, tehnik penentuan sample umumnya dialakukan random sampling. One-group pretest posttest desain merupakan teknik untuk mengetahui pengaruh suatu treatment pada satu grup dengan cara membandingkan keadaannya antara sebelum perlakuan (pretest) dengan keadaan sesudah diberi perlakuan (posttest). Langkah-langkah kegiatan penelitian; petama peneliti melakukan pretest terhadap seluruh siswa kelas/kelompok yang diajadikan subjek penelitian; kedua peneliti memberi treatment kempok tersebut menggunakan pembelajaran TGT; ketiga melakukan posttest terhadap seluruh siswa kelas/kelompok untuk dibandingkan antara keadaan sebelum dengan sesudahnya diberi perlakuan.

Populasi adalah keseluruhan subjek dari sebuah penelitian. Wilayah ini merupakan lingkup penelitian dan dapat dikatakan sebagai populasi. Kelompok besar tersebut dapat dikatakan sebagai orang seperti pendidik, peserta didik, kepala sekolah, dewan sekolah atau sebagai benda berupa media belajar, buku-buku dsb. Hal ini sesuai dengan Syaodih (2013: 250) yang menjelaskan bahwa populasi bukan hanya orang, tetapi juga obyek benda-benda alam lain. Sementara Populasi dalam 
penelitian ini adalah seluruh seluruh siswa yang menjadi bagian dari penelitian yaitu seluruh siswa kelas VIII MTs Roudhotus Syifa.

Sampel dikatakan bagian dari sebuah populasi dan dapat mewakili populasi itu sendiri. Peneliti menggunakan teknik simple random sampling dalam pengambilan sampel. Peneliti lakukan dalam bentuk mengambil secara acak tanpa melihat strata dalam anggota populasi ini. Pertama-tama, peneliti menuliskan namanama kelas pada selembar kertas yang berukuran sama dan beridentitas sama, lalu kertas tersebut kita gulung dan ditaruh di dalam wadah untuk dilakukan pengocokan. Pengocokan lembar kertas yang bertuliskan nama-nama kelas. Setelah pengocokan kertas selesai, diperoleh nama kelas yang siap. Diperoleh sampel yaitu siswa kelas VIII A MTs Roudhotus Syifa yang berjumlah 25 siswa.

\section{HASIL DAN PEMBAHASAN}

Sebelum melakukan treatment, peneliti melakukan pretest terhadap kelas penelitian yang dilanjutkan dengan melakukan pengkoreksian terhadap jawaban. Selanjutnya kegiatan treatment yaitu pelaksanaan pembelajaran TGT yang dimuat dalam langkah-langkah kegiatan penelitian berikut ini:1) Tahap awal, penyampaian topik dan tujuan pembelajaran yaitu mengidentifikasi unsur-unsur kubus dan bagianbagiannya. kemudian menyampaikan bahwa akan dilaksanakan game puzzle dan turnamen; 2) Tahap inti, pada tahap inti memuat lima langkah yaitu (a) Team, membaut 5 grup, tiap grup memuat lima siswa dengan kemampuan heterogen. Kelompok tersebut bertugas untuk mendiskusikan dan menyelesaikan LKS yang diberikan secara berkelompok; (b) Class-Presentation (Penyajian/Presentasi kelas, guru memberikan stimulus berupa LKS dan kerangka bangun ruang sisi datar kepada setiap kelompok sebagai bahan diskusi dan meminta siswa menyelesaikan LKS yaitu menentukan unsur-unsur bangun ruang sisi datar. Selanjutnya perwakilan setiap kelompok memaparkan hasil kerja grup di depan kelas; (c) Game (permainan), pembagian LKS yang berisi potongan-potongan puzzle untuk diselesaikan bersama anggota kelompok. Selama mengerjakan LKS, guru membimbing siswa sebagai fasilitator dalam mengerjakan game puzzle; (d) Tournament (pertandingan/kompetisi), guru menyiapkan meja turnamen dan menyiapkan kartu 
soal turnamen, kartu jawaban dan kartu nomor urut untuk diletakkan disetiap meja turnamen. Guru mengelompokkan siswa berdasarkan kemampuan yang sama pada satu meja turnamen. Turnamen digunakan sebagai pengganti kuis yang dilaksanakan di akhir pertemuan; dan (e) Team -Recognize (penghargaan kelompok), guru mengumumkan hasil penilaian berdasarkan rata-rata poin grup pada saat game puzzle dan turnamen kemudian guru memberikan penghargaan kepada grup heterogen dengan pertingkat tertinggi; 3)Tahap penutup, pada langkah ini bersama-sama membuat rangkuman kegiatan.

Setelah dilakukan kegiatan analisis terhadap penelitian ini diperoleh penambahan hasil prestasi belajar matematika siswa setelah pemberian perlakuan/treatment TGT, yaitu hasil analisis didapatkan $t_{\text {hitung }} 3,18>t_{\text {tabel }} 2,069$, maka Ho yang berbunyi " Pembelajaran kooperatif TGT tidak berpengaruh terhadap Prestasi belajar matematika siswa" ditolak dan Ha yang berbunyi "Pembelajaran kooperatif TGT berpengaruh terhadap Prestasi belajar matematika siswa" diterima. Sesuai dengan hasil analisis tersebut, dapat dismpulkan ada peningkatan dalam pencapaian hasil belajar siswa sebelum dan setelah diterapkan model kooperatif TGT. Sebelum diterapkan model pembelajaran TGT nilai KKM (tuntas) berjumlah 17 (68\%) dari 25 siswa, sebanyak 8 (32\%) siswa nilainya dibawah KKM (tidak tuntas) dengan rata-rata nilai 71,76. Setelah diterapkan model pembelajaran TGT diperoleh 23 (92\%) dinyatakan tuntas dan 2 (8\%) siswa yang belum tuntas dengan rata-rata 79,44. Hasil ini menunjukkan setelah diterapkannya model pembelajaran TGT, hasil belajar lebih baik. diambil kesimpulan model pembelajaran TGT berpengaruh terhadap Prestasi belajar matematika siswa.

\section{KESIMPULAN DAN SARAN}

Berdasarkan hasil pembahasan yang dilakukan maka didapatkan suatu kesimpulan bahwa TGT berpengaruh pada prestasi belajar siswa. Ditunjukkan dari peningkatan hasil belajarnya yaitu sebelum penerapan pembelajaran TGT, rata-rata nilai siswa adalah 71,76 dan setelah diterapkan rata-rata nilai siswa naik 79,44.

Sementara saran yang dapat diberikan adalah: 1) pembelajaran TGT dapat dijadikan sebagai salah satu model pembelajaran yang dapat diterapkan untuk meningkatkan prestasi belajar matematika siswa; 2) Dosen atau peneliti lain 
hendaknya menerapkan model pembelajaran berkelompok agar siswa lebih aktif dalam pembelajaran; 3) Bagi peneliti selanjutnya, diharapkan instrumen yang akan digunakan dalam penelitian sebaiknya divalidasi terlebih dahulu untuk mengetahui tingkat kevalidan instrument dan persiapkan bahan yang akan digunakan dalam penelitian agar berjalan lebih efektif.

\section{REFERENSI}

Hamalik, Oemar. 2001. Perencanaan Pengajaran Berdasarkan Pendekatan Sistem. Jakarta: Bumi Aksara.

Kadir.2005. Pengaruh pendekatan problem posing. Jurnal Pendidikan dan Kebudayaan, hal 223.

Ke, F \& Grabowski, B. 2007. Game playing for Maths Learning: Cooperatif or Not?. Brtish Journal of Educational Technologi, Volume 38 Nomor 2, hal 249-259.

Megawanti, P. 2015. Meretas Permasalahan Pendidikan Di Indonesia. Jurnal Formatif : Jurnal Ilmiah Pendidikan MIPA Volume 2 Nomor 3, hal 227 234.

Sadiman. A. S. 2008. Media Pendidikan. Jakarta: Rajawali Pers.Sagala, Syaiful. 2005. Konsep dan Makna Pembelajaran Untuk Membantu Problematika Belajar dan Mengajar. Bandung: Alfabeta

Slavin, Robert E. 2005. Cooperative Learning. Teori Riset dan Praktek. Terjemahan Narulita Yusron.Tanpa tahun. Bandung: Nusa Media.

Sugiyono. 2011. Metode Penelitian Kombinasi (Mixed Methods). Bandung: afabeta, cv. 